\title{
MAIN FEATURES OF QUALITATIVE LEARNING SPACE AND PRE-SCHOOL CHILDREN LANGUAGE DEVELOPMENT
}

\author{
Agrita Tauriṇa \\ Liepaja University, Latvia
}

\begin{abstract}
The main goal of ongoing transformation of the Latvian pre-school education system is competence-based approach. The essence of this approach is to promote functionality, integrity and practical application of knowledge, explanation of the surroundings, universality of skills, creativity, problem solving. Modern society requests not only for teacher to demonstrate enthusiasm by sharing a deep level of content knowledge, but also necessity of learning space which focus on sensorial senses. It is a way of learning through doing, the process when children obtain knowledge and skills via personal experience, like being creative, flexible, able to analyse, think critically etc. The aim of this article is to analyse successfully created learning space and language development for pre-school age children based on literature analysis and adapted survey results. The empirical study, which took place in Riga, examines these two aspects in pre-school children development of language, communication and the prerequisites of reading and writing. The Latvia State Research Program "Latvian language” No. VPPIZM-2018/2-0002 researchers find out that children who attend minority pre-school education programme have insufficient support in Latvian language environment. Results, conclusions. Qualitative learning space promotes learning abilities and responsible attitudes. This important condition needs to be implemented in competence-based approach to see improvements in pre-school children language and communication development.
\end{abstract}

Keywords: learning space, a pre-school child, language development.

\section{Introduction}

The education reform in Latvia is closely linked to the achievements of the project introducing the Competence Approach in Learning Content and the developed pre-school curriculum. Over the last decade, the philosophy and methodology of the child-centred approach has gained great support in Latvia. It is also supported by the new guidelines developed in 2018, which set out both the content of education and the principles for its implementation for children from the age of 1.5 years.

This new situation makes it necessary for both educators and parents to explore the content offered in the pre-school curriculum, to understand deeper the change in pedagogical approaches and relationship with educational theory and scientific research. As stated in the new program, the child gaining the first 
preschool learning experience should be provided with the basis for future school training. This experience has a significant impact on the development of a child's personality, it is important for children to learn with pleasure, to explore the world, phenomena and relationships. In order to provide children with modern skills education, it is also important to improve the learning approach together with the content. (pre-school curriculum https://mape.skola2030.lv/resources/10).

\section{The analysis of literature}

The competence approach is closely linked to Experiential Education and Learning by Experience. Thus, the knowledge of different theories in general and experiential learning will ensure better success for pre-school teachers in their carrying out educational reform tasks. The new pre-school curriculum emphasises that the teacher, as a planner and an example of good practice, performs the following activities: 1 ) creates a situation in which a child needs to acquire new knowledge, skills or habits, and awareness; discusses the outcome (how, where, how to do this), learns about the child's past experience (what a child already knows); 2) offers new information and opportunities for a diverse learning experience and discusses what assessment criteria should be, directs child's learning and gives support when needed, calls for applying the learned in practice and confirms what has been done; 3 ) assesses the performance of the child and follows their long-term development of awareness and skills, identifying what has been achieved and describing growth; urges the child to assess their own performance on the basis of the criteria set out at the beginning, discusses where the learned skills could still be useful and how to improve the performance (preschool curriculum https://mape.skola2030.lv/resources/10).

John Dewey's educational approach can provide concrete answers to educators and parents, show a way to the creation of the environment needed for child grow, create a dialogue more successfully, allow a child to find a solution in a practical situation, to explore things and to express value-based attitudes. (Dewey, 1938, 12) Therefore, the contribution of each scholar to the implementation of pedagogical ideas gives us the opportunity to see a variety of pedagogical techniques highlighting the characteristics and specificities of a specific age, changing the public attitude to the necessary means of developing the child's personality.

One of the most influential persons of modern educational theory is John Dewey. His approach remains important not only during his lifetime but also nowadays. Even before such theories like the Cultural-Historical Theory by Lev Vygotsky and Genetic Epistemology by Jean Piaget, John Dewey developed progressive ideas on education. (Vygotsky, 1984, 385; Piaget, 1969, 213; Dewey, 1938, 2) The previously stated experience encouraged John Dewey to take 
a different perspective on learning environments and successful conditions for children development. "Their ideas on the growth and development of children, the importance of learning by experience from interaction with natural objects and the natural environment, and the role of schools and teachers in society, set the stage for John Dewey and progressive education movement of the $20^{\text {th }}$ century. Experiential educators should still discuss and debate their ideas because the issues they discuss are still relevant.” (Smith \& Knapp, 2011, 31). Dewey points out the importance of appropriate learning time when children interact with their environment and they are actively involved with the school curriculum. He also goes on to say that human beings better learn through a hands-on approach and disagree with thinkers of his time who support behaviourism. He states that behaviourism ideas are too simplistic and cannot fully explain complex learning processes. Dewey emphasizes the idea that children should take active part in the process of their own learning and a passive reception of knowledge would only create a situation of imperfect skill acquisition. It is crucial to give children learning opportunities which will make them link present content to previous experiences and knowledge. (Dewey, 1938, 5) Learning is a life-long (continuous) process which is based on experience. "The principle of continuity of experience means that each experience deals with something that has gone before and changes somewhat the quality of those who come after [...] What he learned in terms of knowledge and skill in a single situation becomes a tool for interrupting and effectively addressing the situation that follows. The process lasts as long as life and learning continue.” (Massari et at., 2018, 19). Dewey creates a completely different learning methodology by stating the importance of getting new knowledge through impressions made upon us by natural objects. Later on, this becomes known as experiential education and the base of similar approaches such as problem-based learning. (Dewey, 1938, 33)

At first, it can look like Dewey's approach to learning processes may not particularly stand out today, but in the early and mid-1900s, his ideas of education were completely different from that time's system of schooling. He created the child-centred approach which placed great importance on learning connected to needs and interests of the child and made others notice the significance of exploration done by children. (Dewey, 1938, 4) According to Dewey's principles, the role of the teacher is to serve more as a facilitator than as an instructor. The teacher should notice interests of children and then help them to develop their specific skills. "Unlike the traditional class situation where pupils can complete with each other or remain uninvolved or unmotivated, if the teaching process is structured according to the principles of experiential learning in which the teacher facilitates progress and the focus is on the learning process and not on the product, then the pupils will engage in direct experience, cooperate and learn one from each other about situations and problems of the real environments. Experiential 
learning advocates claim that pupils will be more motivated to learn when they have a personal stake in the topic than when they are asked to review a topic or read a chapter in the textbooks that they are not directly involved in and do not see the meaning." (Massari et al., 2018, 22). This kind of situations creates good experience and makes children want to find new information and develop new skills. Following these principles, the teacher can increase children's desire to explore what the world can offer to them. As it was said before, the teacher should notice students, their talents and interests and then opportunities and ways how they can fully develop specific skills.

Of course, it is very important to make educational process gradual. That is why teachers and parents should develop each skill step by step at an appropriate time. One of main tasks of preschool is to prepare children to school environment by developing self-care skills. One way how to develop these skills is to teach a child to take responsibility. Responsibilities in preschool can include cleaning work place after work/play, taking care of one's clothes end personal items, informing adults about dangerous situations, following roles for group and preschool, and other responsibilities. Introducing these skills and including them in child's daily life can develop a stable rhythm of life which will increase the sense of security and prepare children for the future. For children, it is important to offer different ways how to develop self-care skills and explain in what situations these skills will be useful. Furthermore, for gradual skill development, it would be useful to think the learning process over and set realistic goals for a teacher and for students. To promote children to take care of their responsibilities, the teachers created tasks that each child needs to do every day of the week, for example, making sure that they clean working area after work/play, helping the teacher assistant to prepare tables for meal time, cleaning after themselves, or helping others with difficult tasks. In the beginning of the day the teacher tells children of all the things planned for a day or days ahead, so that children can understand what needs to be done. The teacher also can give children play activities and assignments that needs to be done by the end of the day, and children can decide how fast or slow the task should be done. At the same time, making children feel the responsibility and think of all the work that should be done by the end of the day makes them feel as a partner in the decision-making process. Children are eager to help and take responsibility, so preschool is especially suited for developing the ability to take responsibility, to plan the time for completing all the tasks needed to be done, and to learn the skills of self-service. It is important to understand and explain to children that parents will not always be by their side and able to help. By developing self-care skills of children, parents and teachers make the adaptation process easier.

Early years' education has always placed great emphasis on the environment, in both indoor and outdoor education (Pestalozzi, Froebel, Montessori, 
Dewey, etc.). Moreover, access to the natural environment in the form of outdoor learning has become an important part of several early childhood curricula and frameworks, such as that of England, Scotland, Australia, and parts of Canada (Barrable, 2019). Giving chance to explore freely and develop child's skills in a thoughtfully organized and safe environment is a much more effective way to manage positive behaviour and encourage learning process than setting up an environment where the adult is all the time redirecting children. A well-organized environment will keep children interested in activities and prevent misbehaving. It is important to understand that the term environment includes not only a safe place where children learn and develop domain fields such as cognitive, communication, social and motor ones, but also age and interests appropriate materials, equipment and activities.

One of the concepts of a well-organized and prepared environment which is created to encourage the independent learning and exploration process is offered by Maria Montessori. The specialist in Maria Montessori work, Michael J. Swiderski believes that she is a representative person who started an educational reform movement. The Montessori school environment was arranged according to subject areas, e.g., cooking, cleaning, gardening, art, caring for animals, library corner. Children were always free to move around the room instead of staying at desks. There was no limit to how long children could work on something they had chosen. Another related element of the Montessori method was the "decentring" of the teacher. The teacher was a "keeper of the environment". When children got into activities, the task of the teacher was to keenly observe and to intervene from the periphery. The focus was on selfrealisation through independent activities, and the diligence of the teacher to unobtrusively orchestrate the integrity of the environment (Swiderski, 2011, 201). In other words, the focus is not on teacher and teaching methods but on children. By careful observation and planning, teachers spot the direction where the child is heading at and provide all conditions to help them succeed in what was planned. By doing this, teachers allow children to learn from their own insights and can think of possible explanations. Thus, the teacher is a link between children and thoughtfully designed environment.

Patrick R. Frierson defines Montessori environment as a constructing environment (primarily at school) providing external support for children's already available capabilities. With respect to self-determination, she seeks an environment that facilitates two aspects. First, an environment should facilitate children's self-directed, persistent, attentive interest in activities. With it comes that self-control involved in pursuing a chosen task to completion with order and excellence. Secondly, and equally importantly, the environment should provide occasions to cultivate self-discipline involved in respect for others, social cooperation, and deliberate submission to legitimate authority 
(Frierson, 2016, 340). Both aspects are important for children's successful development. By having appropriate self-control, children will be able to solve problems successfully and have higher academic achievements as well. They can experience frustration in a more effective way and have better developed critical thinking skills. Of course, struggles can be met not only with self-control but also with self-discipline. When the adult is teaching these skills, he needs to find ageappropriate tools to help children practice and acquire self-discipline and control.

Vidnere draw attention to the concept of environment and space and the following components of the school professional space have been listed:

- technical materials;

- educational;

- $\quad$ social;

- cultural;

- $\quad$ subjects and activities;

- $\quad$ interactively communicative (Vidnere, 2019, 47).

She supports the idea that the educational area of schools is a structure in which certain classes are interlinked and extended: informative educational, culturally educational, theoretical education and practical education (Vidnere, 2019, 46).

The human need for achievements involves self-empowerment. If these needs are met, the pupil is aware of the opportunities and skills to achieve the goal, he is well equipped and skilled to get out of current hardships. He follows his own achievements, has skills to learn, perform day-to-day works and is able to assess them adequately. If a pupil does not need self-empowerment, his behaviour starts demonstrating adult dependency. The pupil underestimates his achievements, feeling he has failed and got a lack of tenacity, a lack of skills, and then leaving jobs uncommitted. Failing to meet these needs can lead to the sense of low self-esteem, depression and worry about the future (Spona, 2006).

The development of a child's learning and the overall parenting process depend on the feelings of a child. It's important how a child treats her/himself, how adults and peers experience their luck and failure (Svence, 1999).

In satisfying the needs in information, internal psychological transformation, development, self-awareness-raising of learning take place. Unmet needs, especially in self-awareness, peer and teacher learning, lead to children's negative behaviour (Spona, 2006).

By encouraging children, we can help develop their internal forces and courage to move towards a positive goal. The purpose of encouragement is to shift children's thinking from I can't do it to I'll do it, and teaching them to focus not on the result but on the process and to gain pleasure from it. Encouragement is the most important thing we need (Kanepeja, 2012). 
If a child fails, it reduces the desire to make an effort, causes indifference and intellectual passivity (Baltusite, 2006).

Kanepeja and Liegeniece believe that the joy of a child arises from the ability to accomplish something if his or her actions are assessed positively. The positive assessment raises the child's self-awareness. The self-awareness of a child is driven by understanding who he is, what his qualities are, how others treat him, and how this attitude appears (Kaņepēja \& Lieǵeniece, 2012).

At the pre-school age, the family plays the most important role in the development of the child. Positive learning experience based on positive social and cognitive experience depends on the effects of parenting. The best way of parenting at the preschool age, and not only at this age, is parental behaviour as a model. The child learns more from what she/he sees than from what she/he hears (Beltusite, 2006).

In Latvia learning problems need to be addressed by educators in close cooperation with parents, especially in situations where the experience of using the Latvian language in the family is insufficient. In order for the educator to better plan and advance the learning of the Latvian language of the child, it is important to explore the opinion of parents or adults involved in the care of the child regarding the provision of the Latvian language environment.

\section{The results of the empirical research}

The research team is grateful to the Latvia State Research Program "Latvian language” No. VPPIZM-2018/2-0002 for the considerable support during project implementation (2018 - 2019). The Project is fully suited for Latvian or adapted by an international survey of parents of bilingual children in Utrecht Bilingual Language Exposure Calculator or UBiLEC developed in Utrecht (Netherlands), which is in practical use in the work of the project. It is a complex of measures that helps to understand the interests of the child, the occupation of the parents, the education and the experience of using the Latvian language of family members. Parents are very widely surveyed about their children's linguistic experience at home, in the kindergarten, in other lessons and their spare time. For example, answers to the question "Where did your child hear Latvian for the first time?" give the educator a chance to get to know the environment in which the child has first had an interest in the Latvian language. It is important for the educator to raise awareness of the need for greater use of the Latvian language for parents, as well as to provide positive support for the child's attempts to speak Latvian.

The survey covers the question "How well does your child know/understand Latvian?”, which helps to assess the quality and level of the language to be learned. When the teacher receives information on this issue, the teacher can more 
Taurina, 2020. Main Features of Qualitative Learning Space and Pre-School Children Language Development

accurately launch a conversation on promoting the development of a child's speech, as well as better perform pedagogical observations in the kindergarten environment.

The survey is designed for evaluating the language of bilingual children. Two groups of children are identified in the work of the project: a group of bilingual children attending the Latvian pre-school education programme and children attending a minority programme, which includes learning the Latvian language. Survey took place in capital city of Latvia.

The results of the survey on the use of Latvian in the family and on family members who can support children in the acquisition of Latvian are reproduced in two tables (tables 1 and 2). The call in the survey was as follows: "Think about the people your child talks to regularly at home, please. Mark them with "+” in the table, indicating how often each of them speaks to the child in Latvian and Russian.

This is important for the educator to make concrete proposals to a family about people who the child could have the closest contact for promoting Latvian learning.

Table 1 Information on Latvian usage and people regularly talking to children at home (bilingual children attending a pre-school education programme in Latvian)

\begin{tabular}{|c|c|c|c|c|c|c|c|}
\hline & $\begin{array}{c}\text { Only } \\
\text { Russian }\end{array}$ & $\begin{array}{c}\text { Hardly } \\
\text { ever } \\
\text { Latvian, } \\
\text { almost } \\
\text { always } \\
\text { Russian }\end{array}$ & $\begin{array}{c}\text { Seldom } \\
\text { Latvian, } \\
\text { usually } \\
\text { Russian }\end{array}$ & $\begin{array}{c}50 \% \\
\text { Latvian, } \\
50 \% \\
\text { Russian }\end{array}$ & $\begin{array}{l}\text { Usually } \\
\text { Latvian, } \\
\text { seldom } \\
\text { Russian }\end{array}$ & $\begin{array}{c}\text { Almost } \\
\text { always } \\
\text { Latvian, } \\
\text { hardly } \\
\text { ever } \\
\text { Russian }\end{array}$ & $\begin{array}{c}\text { Only } \\
\text { Latvian }\end{array}$ \\
\hline Mother & 3 & 3 & 2 & & & & 2 \\
\hline Father & 4 & 2 & & 1 & 1 & & 2 \\
\hline Sister/brother & 1 & 2 & 1 & 2 & & 1 & \\
\hline Sister/brother & & 1 & 1 & & & & \\
\hline Sister/brother & 1 & & & & & & \\
\hline Grandmother I & 5 & 1 & & & 1 & & 2 \\
\hline Grandmother II & 5 & & & & & 1 & \\
\hline Grandfather I & 4 & & 1 & & 1 & & 1 \\
\hline Grandfather II & 3 & & & & & & 1 \\
\hline Babysitter & 1 & & & & & & 1 \\
\hline
\end{tabular}

The first table shows that 9 adults communicate with children only in Latvian, but the table below illustrates the situation in which only one person communicates with children using the Latvian language. It means that children who attend minority pre-school education programme have insufficient support for the Latvian language development. 
Proceedings of the International Scientific Conference. Volume III, May $22^{\text {th }}-23^{\text {th }}$, 2020. 743-753

Table 2 Information on Latvian usage and people regularly talking to children at home (children attending a minority pre-school education programme and learning Latvian)

\begin{tabular}{|c|c|c|c|c|c|c|c|}
\hline & $\begin{array}{c}\text { Only } \\
\text { Russian }\end{array}$ & $\begin{array}{c}\text { Hardly } \\
\text { ever } \\
\text { Latvian, } \\
\text { almost } \\
\text { always } \\
\text { Russian }\end{array}$ & $\begin{array}{c}\text { Seldom } \\
\text { Latvian, } \\
\text { usually } \\
\text { Russian }\end{array}$ & $\begin{array}{c}50 \% \\
\text { Latvian, } \\
50 \% \\
\text { Russian }\end{array}$ & $\begin{array}{c}\text { Usually } \\
\text { Latvian, } \\
\text { seldom } \\
\text { Russian }\end{array}$ & $\begin{array}{c}\text { Almost } \\
\text { always } \\
\text { Latvian, } \\
\text { hardly } \\
\text { ever } \\
\text { Russian }\end{array}$ & $\begin{array}{c}\text { Only } \\
\text { Latvian }\end{array}$ \\
\hline Mother & 6 & 1 & 2 & & 1 & & \\
\hline Father & 4 & 2 & 1 & & & & \\
\hline Sister/brother & 4 & 1 & 1 & & & & \\
\hline Sister/brother & 1 & & & & & & \\
\hline \multicolumn{8}{|l|}{ Sister/brother } \\
\hline Grandmother I & 4 & 1 & & & & & \\
\hline Grandmother II & 5 & & & & & & \\
\hline Grandfather I & 6 & 1 & & & & & \\
\hline Grandfather II & 4 & 1 & & & & & \\
\hline Babysitter & 2 & & 1 & & & & 1 \\
\hline
\end{tabular}

To make clear how well these people understand or speak the language, they are asked at what age each of them came into contact with the Latvian language. However, the question "How often does your child speak Latvian or Russian with you or with another family member?” helps to find out about the child's conversations with each of the named people. A survey of parents helps to clarify the sequence of learning the languages by a bilingual child, the linguistic environment for the various stages of the child's development, and the role of people in the child's immediate neighbourhood in the development of a balanced bilingualism. It helps to clarify the intensity of language usage, as well as partly the quality of the language within and outside the family (i.e. at educational establishments, in different interest groups, on holidays). The adequacy of answers depends on parental attitudes and their feeling of responsibility, but in general, this survey is also an essential part of the learning and development of the child's language.

Fisher admits that the child grows better in a subject when he teaches it to others. This method below are intended to help children:

- Decomposition - invite children to summarize what they read or explain why they learned it, encouraging them to focus their attention on the main thoughts in the fragment on the story, and to check how they understood it;

- $\quad$ Questioning - invite children to ask questions about the material what they read or learnt, urging attention to the main thoughts and the way they understood them; 
- $\quad$ Finding out - ask children to find out every place in the text that is difficult for them to take a critical assessment of their level of knowledge;

- $\quad$ Prediction - direct children to think more broadly beyond the limits of a given text and situation, so that they draw conclusions and justify them according to indications found in the content or structure of the text (Fisers, 2005).

The aim of the education reform and competence approach is an inquisitive, creative and vibrant child living a healthy, safe and active life, encouraged to act independently, interested in learning and pleased to gain the experience of her/himself, others, the surrounding world and interaction within it (Skola2030).

If we believe that it is essential to promote independence, objectivity, the ability to justify and affect decisions, which are made by others, if we respect the child's personality, then we choose to justify emotionally, enthusiastically or practically the various ideas to be pursued and agree with the child on the actions to be taken (Taurina, 2015, 96).

Puren stresses that the competence approach to learning plays an important role, but self-vision develops only if the child is aware of the importance of the obtained information in his life and see possibilities to use this information. This way leads to it through acquiring thinking and learning skills (Purens, 2017).

\section{Conclusions}

1. Children develop skills in action, observe the attitude of adults, imitate them and try various techniques. Children no longer have to passively watch adults perform different activities, instead, they can be active themselves.

2. Children have difficulties in reaching agreement with peers, in adhering to rules - they do not always want to complete work, evaluating what has been accomplished, and expressing judgment. Interest in different topics, getting to know different subjects and expressing opinions on what has been learned or accomplished

3. The teachers' effort to create a positive psychological microclimate in classroom is highly valued, which is a very important prerequisite for the development of students' motivation to learn. An important role in the pedagogical process has also been allocated to different aspects of inclusive education.

4. Important focus of the pedagogical process is currently the connection of the study content with real life, since the competence approach requires the purposeful acquisition of knowledge where each learner understands why he or she is learning the offered study content. 


\section{References}

Barrable, A. (2019). Refocusing Environmental Education in the Early Year: A Brief Introduction to a Pedagogy for Connection. Education sciences, 9, 61, 1-8. Retrieved from https://www.researchgate.net/publication/331873838_Refocusing_Environmental_ Education_in_the_Early_Years_A_Brief_Introduction_to_a_Pedagogy_for_Connection Baltušìte, R. (2006). Skolotāja loma mācī̌sanās motivāaijā. Rīga: Izdevniecība RaKa.

Dewey, J. (1938). Experience and Education. New York: Kappa Delta Fi. Retrieved from https://archive.org/details/ExperienceAndEducation-JohnDewey/mode/2up

Fišers, R. (2005). Mācīsim bērniem mācīties. Rīga: Izdevniecība RAKA.

Frierson, P.R. (2016). Making Room for Children's Autonomy: Maria Montessori's Case for Seeing Children's Incapacity for Autonomy as an External Failing. Journal of Philosophy of Education, 50, 3. Retrieved from https://onlinelibrary.wiley.com/doi/abs/10.1111/ 1467-9752.12134

Kaņepēja, R., Lieǵeniece, D., Mangule, I., Ukstiņa, R., Dzintere, D., Stangaine, I., Miḳelsone, I., Millere, I., Platpers, A., \& Gaugere, Z. (2012). Cel̦ā uz skolu. Bērnu sagatavošana pamatizglītības ieguvei. Rīga: Apgāds Zvaigzne ABC.

Massari, G.A., Miron, F.M., Kamantauskiene, V., Alat, Z., Mesquita, C., Tzakosta, M., Verheij, J.K., \& Zirina, T. (2018). A Handbook on Experiential Education. Pedagogical guidelines for teachers and parents. Romania: Editura Universității Alexandru Ioan Cuza din Iași.

Piazhe, Zh. (1969). Izbrannye psihologicheskie trudy. Moskva: Prosveshhenie. Retrieved from http://elib.gnpbu.ru/text/piazhe_izbrannye-psihologicheskie-trudy_1969/go,14;fs,1/

Purēns, V. (2017). Kā attīstīt kompetenci. Rīga: Izdevniecība RaKa.

Skola 2030, Ministru kabineta "Noteikumi par valsts pirmsskolas izglìtības vadlīnijām un pirmsskolas izglītības programmu paraugiem" (2019). Retrieved from http://www.skola 2030.lv/lv/skolotajiem/izglitibas-pakapes/pirmsskola

Smith, T.E., \& Knapp, C.E. (2011). Sourcebook of Experiential Education. Key Thinkers and Their Contributions. New York and London: Routledge.

Svence, G. (1999). Attīstības psihologija. Rīga: Apgāds Zvaigzne ABC.

Swiderski, M.J. (2011). Sourcebook of Experiential Education. Key Thinkers and Their Contributions. In Thomas E. Smith \& Knapp Cliford. E. (Ed.), Maria Montessori Founding Mother of Experiential Education? (pp. 197-207). New York and London: Routledge.

Špona, A. (2006). Audzināšanas process teorijā un praksē. Rīga: Izdevniecība RaKa.

Tauriņa, A. (2015). Bērna sasniegumu veicināšana pirmsskolā. No A. Špona (sast.), Bērna jautājumi - personības izaugsmes pamats (86-108). Rīga: Izdevniecība RaKa.

Vidnere, M. (2019). Skolotāja profesionālā identitāte. No A. Šteinberga (sast.), Skolotāja profesionālās identitātes teorētiskie pamati (24-49). Rīga: RTU Izdevniecība.

Vygotskij, L.S. (1984). Sobranie sochinenij v 6 t.: T. 4: Detskaja psihologija. Moskva: Pedagogika. Retrieved from http://elib.gnpbu.ru/text/vygotsky_ss-v-6tt_t4_1984/ go,384;fs,1/ 